\title{
Towards a shared worldview on e-skills: A discourse between government, industry and academia on the ICT skills paradox
}

\author{
Hossana Twinomurinzi ${ }^{\mathrm{a}}$, Adrian Schofield $^{\mathrm{b}}$, Lise Hagen $^{\mathrm{c}}$, Seipati Ditsoane-Molefe ${ }^{\mathrm{d}}$, Ndivhoniswani $^{-}$ \\ A. Tshidzumba \\ a School of Computing, University of South Africa, South Africa \\ b Joburg Centre for Software Engineering, University of the Witwatersrand, South Africa \\ ${ }^{c}$ Software and IT Services Africa, International Data Corporation South Africa \\ ${ }^{d}$ Critical Skills Acquisition, Department of Home Affairs, South Africa \\ e Department of Journalism, Tshwane University of Technology, South Africa
}

\begin{abstract}
There is often criticism from industry that there are not enough ICT skilled professionals in the market, and that the situation may only be getting worse. On the other hand, some ICT graduates struggle to find jobs. This phenomenon is referred to as the ICT skills paradox. A recent panel at the 2015 South Africa Computer Lecturers Association (SACLA) conference composed of leaders from industry, academia and government discussed their perspectives on the ICT skills paradox. The Habermasian goal of the panel, and the objective of this research, was to make sense of the paradox from the different sectors' worldviews involved in ICT skills, and to identify mutually acceptable means of dealing with the paradox. The discourse of the panel session was analysed using techniques from grounded theory. There were three overarching findings; South Africa needs a formal accreditation body which is sensitive to and reflective of the unique local contexts; there is a need for a central coordinating agency on ICT skills between academia, government and industry; and rather than attempt to define ICT or ICT skills, efforts should be placed on embracing transdisciplinary practices. Based on the findings, the paper makes recommendations on how to deal with the contrasts, the dynamism of the ICT sector, and how the current ICT skills paradox could be resolved in South Africa and similar developing country contexts. The paper also makes a contribution to ICT theory on how to achieve consensus and implement ICT strategies from seemingly contradictory sectors using Habermas' theory on social interactions.
\end{abstract}

Keywords: ICT skills shortage, e-skills, grounded theory, theory of communicative action, transdisciplinarity

Categories: • Applied computing $\sim$ Governmental regulations $\bullet$ Applied computing $\sim$ Government technology policy

\section{Email:}

Hossana Twinomurinzi twinoh@unisa.ac.za (CORRESPONDING),

Article history:

Adrian Schofield Adrian.Schofield@wits.ac.za,

Lise Hagen Ihagen@idc.com,

Seipati Ditsoane-Molefe seipatid@yahoo.com,

Received: 7 Aug 2016

Accepted: 14 Nov 2017

Available online: 8 Dec 2017

Ndivhoniswani A. Tshidzumba tshidzumbaNA@tut.ac.za

Twinomurinzi, H., et al. (2017). Towards a shared worldview on e-skills: A discourse between government, industry and academia on the ICT skills paradox. South African Computer Journal 29(3), 215-237. https://doi.org/10.18489/ sacj.v29i3.408

Copyright (C) the author(s); published under a Creative Commons NonCommercial 4.0 License (CC BY-NC 4.0).

SACJ is a publication of the South African Institute of Computer Scientists and Information Technologists. ISSN 1015-7999 (print) ISSN 2313-7835 (online). 


\section{INTRODUCTION}

The global discourse on ICT skills shortages suggests that there are not enough skilled people to fill the gaps that are created by the rapid advancement of ICT (The Information Economy Council, 2014; Schofield, 2014). The logical solution for aspiring ICT graduates is that obtaining any type of skills in ICT ought to increase the chances of having a lucrative career today and into the future. Careers in ICT are often spoken about with a degree of sureness as a field in which skilled individuals can easily and quickly find employment (Career Junction, 2017) in any nation or even in an entrepreneurial career. It is therefore surprising when a number of articles suggest that ICT graduates also battle to find employment, for years sometimes (Oluwajodu, Blaauw, Greyling, \& Kleynhans, 2015; Tomlinson \& Tomlinson, 2008; Twinomurinzi, 2015). It is even more surprising when employers express a dissatisfaction with the employability of ICT graduates (A. P. Calitz, Greyling, \& Cullen, 2014; Coulson, 2014; Gefen, Ragowsky, Miller, Licker, \& Stern, 2015). This paper attempts to make sense of the phenomenon of the ICT skills paradox; individuals with ICT skills on demand but struggling to be employed. The paper focused specifically on South Africa and the perspective of the three important stakeholders involved in ICT skills, that is, government, business and academia.

In May 2015, a panel was held at the 2015 SACLA conference in Johannesburg, South Africa. The four-person panel consisted of leaders from government, industry, a government state agency and a research organization. The focus of the panel was to bring together leaders and academics from the key sectors of ICT to discuss the ICT skills shortage in South Africa. The primary research objective was to make sense of the ICT paradox as guided by Jürgen Habermas' notion on how to create a better world.

Habermas (1972) suggests that local communities and collectives have a shared history which is unique to them, and it is therefore impractical to expect outside interventions to create a better local society. Habermas argues that social changes to the collective need to occur from within the collective in an evolutionary process where all those affected by the intended and unintended consequences will accept them.

Habermas (1972) recommends that discourse is the most effective way to unravel existing assumptions and create the shared and mutually accepted views within a collective. Habermas (Lyytinen \& Klein, 1985) identifies two general types of social interactions: communicative action and strategic action. Strategic actions follow rules of rational choice and are appraised from the standpoint of efficiency in influencing decisions of rational opponents. Communicative action, on the other hand, takes place through language and aims to achieve mutual understanding. Communicative action focuses on agreement, a common understanding of norms, meanings and values, and on maintaining social relationships (Habermas, 1979).

Discourse as it occurs in a panel session ensures that all voices receive an equal opportunity to share on the issues for discussion i.e. an informed, democratic and publicly open debate. In such discourse, no force should influence the outcome. The choice of a panel session as the means to achieve the research objective was therefore fitting and reflected the essence of communicative action. Each of the panelists presented their perspective about the ICT skills shortage in front of an audience of ICT academics and practitioners from across South Africa. The panelists and the audience 
discussed perspectives surrounding the ICT skills shortage as it presents itself. The secondary research objective was therefore to stimulate open discourse between industry, academia and government and move towards a shared view on what could be done to deal with the ICT skills paradox.

The remainder of the paper is structured as follows: the next section presents the literature review on ICT skills, curricula and the South African setting. The following section describes the research method and analysis approaches adopted to make sense of the rich panel discussion. It is followed by the findings section. The final section on conclusions makes inferences and recommendations based on the findings.

\section{LITERATURE REVIEW}

In this section, the literature on defining ICT and the accompanying challenge of succinctly defining ICT skills in a dynamic and fast-changing context is presented. It is followed by literature on curricula and accreditation. The final sub-section presents the literature on ICT skills from the national perspective of South Africa.

\subsection{The meaning of ICT skills and ICT}

A skill is the learned capacity to carry out pre-determined results often with the minimum outlay of time, energy, or both (Dreyfus \& Dreyfus, 1980). A skill has a great deal to do with experience and is related to the context in which the skill is applied (Sahay, Mukherjee, Yaqub, \& Westrup, 2015). In attempting to define ICT skills, there is a challenge of where to set the boundaries in order to create a succinct definition (Zuppo, 2012). ICT is today very pervasive and is embedded in almost every menial task and critical function. ICT can now be found in hospitals, schools, rural homes, deep villages, in clubs, and in the most unexpected places. The transdisciplinary nature of ICT means that with every crossing between ICT and a domain area, a new form of ICT is created, along with the required skill sets to support competence in the new ICT (Twinomurinzi, 2012). This pervasiveness is arguably one of the key reasons that there is greater demand for ICT skills that enable the cross between ICT and other domain areas. Reports from the largest online recruiting agency in South Africa support the suggestion that skills in ICT, particularly in software development, have been the highest in demand and have continued to show growth for more than five years (Career Junction, 2017).

This paper found the most appropriate inclination to defining ICT through broad categorizations. ICT has been implicitly and explicitly defined under three broad perspectives: the usage, the domain impacts and the contextual views (Orlikowski \& Iacono, 2001; Sein \& Harindranath, 2004; Zuppo, 2012). In terms of the usage, ICT is defined in terms of how it is used as a commodity, driver or enabler (Zuppo, 2012). The domain impacts are differentiated dependent on the impact that ICT has on the domain (Sein \& Harindranath, 2004). For example in the domain of human development, the impact is seen on three levels: primary impact (ICT substitutes existing means), secondary impact (the ICT is proliferated) and tertiary impact (new social structures are created because of the ICT). 
The contextual views are seen in five broad categories; the tool view, the proxy view, the ensemble view, the computational view and the nominal view (Orlikowski \& Iacono, 2001).

In the tool view, ICT is defined as a tool to perform a function for example to substitute manual labour. In the tool view, the context in which ICT is applied is not necessarily taken into account.

In the proxy view, the focus is on the essential aspect or property that ICT adds. The value is often measured in individual perceptions, diffusion rates or even money spent. For example, measuring why and how individuals adopt ICT.

The ensemble view sees ICT as part of a dynamic network in a social context that includes people, their relationships, and other artefacts: for example, when ICT enables significant social relationships and is designed to embody those relationships.

The computational view of ICT is mainly interested in the capabilities of ICT to represent, manipulate, store, retrieve, and transmit information, thereby supporting, processing, modeling, or simulating aspects of the world: for example, programming algorithms. In the nominal view, ICT is only invoked in name but not in fact. For example, salaries of software developers.

The above broad categorizations of ICT suggest that the results expected from ICT are better defined in ranges and not using strict technical limitations. It follows therefore that assigning a succinct definition to the meaning of ICT skills, the learned capacity to carry out pre-defined ICT results, is similarly replete with boundary complexities and is better done using ranges. This paper therefore makes the proposition $P_{1}$ that the inability to succinctly box ICT into one meaning could have something to do with the ICT skills paradox.

$P_{1}$ : The inability to succinctly box ICT into one meaning could have something to do with the ICT skills paradox.

Despite the complexity in defining ICT and hence ICT skills, there have been efforts by academics, practitioners, national and international agencies to define, measure and steer the direction of ICT skills. The efforts are discussed in the next sections under the accreditation and e-skills discourse.

\subsection{ICT skills curricula and accreditation}

Accreditation is a means by which organised disciplines agree on the quality standards used to measure competences and credibility in that domain. In the discipline of ICT, there are two dominant accreditation bodies that have pioneered accreditation of tertiary ICT skills: the American Accreditation Board for Engineering and Technology (ABET) and the Chartered Institute of IT, formerly better-known as the British Computing Society (BCS).

ABET considers the student, the academic environment, the academic content and the curriculum of ICT academic programmes ${ }^{1}$. ABET identifies ICT skills curriculums as falling in either of three categories: Computer Science, Information Systems and Information Technology. BCS considers a broader range of ICT skills, ranging from basic ICT skills such as computer literacy to specialised tertiary ICT skills curriculum that include mathematical applications in computer science.

\footnotetext{
${ }^{1}$ https://abet.org/
} 
There is a Computing Seoul Accord between organizations responsible for accrediting ICT programmes in Australia, Canada, Chinese Taipei, Hong Kong, Japan, Korea, the United Kingdom, and the United States. The Seoul Accord does not have any representation from Africa or South America.

There are nonetheless attempts in South Africa at formalising an accreditation organisation that resonates with the ICT skills needed in South Africa. The South African Computing Accreditation Board (SACAB) was established by the Institute of IT Professionals South Africa (IITPSA) and the South African Institute of Computer Scientists and Information Technologists (SAICSIT) in 2014 (Southern African Computer Lecturers' Association, 2014). The objective is for SACAB to become part of the Seoul Accord. Currently, accreditation documentation and requirements for South African Universities have been compiled by SACAB and presented at the SACLA 2017 conference (A. Calitz, 2017).

This paper therefore makes the second proposition $P_{2}$ :

$P_{2}$ : Accreditation of ICT skills curricula may assist in making sense of ICT skills in South Africa.

In the next section, the paper discusses international and national attempts to focus ICT skills in their local contexts.

\subsection{Contextualising ICT skills to national strategies}

The concept of e-skills relates to adopting creative and innovative uses of ICT locally, with the fundamental argument that for local ICT innovations to occur, there need to be in place skill competencies ranging from digital literacy to high-end specialist ICT skills such as computer science (Runciman, 2015).

The e-skills strategies to innovate ICT skills locally differ from nation to nation. For example, Malaysia and India ensure that foreign direct investments in ICT are channeled through indigenous companies. Malaysia requires multinational corporations to employ local resources so that the ICT skills will remain in Malaysia. South Korea places the emphasis on building human capital through education and creating high-tech industries that will absorb local critical ICT skills (Lazonick, 2006). In South Africa, there were multisector attempts at increasing the level of ICT skills in South Africa promoted by the iNeSI initiative under the label of e-Skilling South Africa. The initiative is currently under the government agency National Electronic Media Institute (NEMISA) (Ikamva National eSkills Institute, n.d.).

The consistent theme that runs through the different national e-skilling agendas is the recognition that ICT skills are only one part of a wider discussion on stirring local economic growth, and should therefore form part of a wider national economic strategy. For example, countries with a strong socioeconomic developmental agenda like South Africa are better off pursuing e-skilling strategies that complement, support and drive the National Development Plan (NDP). The paper therefore makes the third proposition $P_{3}$ that ICT skills in South Africa should be guided and predominantly influenced by the NDP.

$P_{3}$ : ICT skills strategies in South Africa should be influenced by the NDP. 
In the next section, the means of inquiry to investigate the propositions $P_{1-3}$ and make sense of the ICT skills paradox in South Africa are presented.

\section{RESEARCH METHODS AND ANALYSIS}

The paper used a qualitative inductive epistemology in placing paramount value on the importance of context and the lived experience of human beings (Everhart, 1986). The qualitative inductive approach enabled the creation of new understandings about the possibility of bringing together the different perspectives of the ICT skills challenge in South Africa using a panel discussion.

In terms of analysis method, the paper employed techniques from Grounded Theory. In particular, the paper adopted Glaser's 'emergent' method (Glaser, 1992) in preference to Strauss' method 1999. Two approaches to Grounded Theory arose because Glaser and Strauss disagreed on method. According to Strauss $(1987,1990)$ the researcher must be guided by a theoretical perspective prior to data collection. However, Glaser (1992) considered it absurd and untrue to the fundamental spirit of Grounded Theory to begin with a theoretical perspective before conducting research. For Glaser (1992), a theoretical perspective results in a biased substantive theory. Glaser believed that a researcher should have no bias before entering into the field. Kelle (2007) refers to these divergent approaches as a conflict between whether categories emerge (Glaser, 1992) or are forced out from empirical data (Strauss, 1987).

Grounded Theory techniques have been shown to be helpful when analysing data collected through discourse (Charmaz \& Mitchell, 2001) by comparing data with data to elicit concepts and categories, comparing the data with emergent categories, and finally demonstrating relations between concepts and categories using memos (Glaser, 1978; Glaser \& Strauss, 1999; Lofland \& Lofland, 1984). Figure 1 below illustrates the process recommended by Coyne (2009) and was followed in this paper using Atlas.ti software.

The next section presents the findings that emerged from the analysis process.

\section{FINDINGS}

The first stage of grounded theory analysis of the panel discussion, line to line substantive coding, elicited 108 codes. Table 1 below presents the top five most frequently occurring codes. The full list of codes is presented in Appendix A.

The next stage after coding is to group codes into categories. The process of categorising is an eclectic process and some codes will fall into more than one category. Such multifaceted codes are copied across into the related categories into which they fall. Atlas.ti uses the term 'families'. Categorising the codes resulted in 15 families (Table 2). The list of code families and the codes placed within a code family is presented in the online supplement ${ }^{2}$.

A parallel and continuous Grounded Theory activity that runs across the process of coding and categorising is memo writing. Memo writing is when statements are generated about the

\footnotetext{
${ }^{2}$ http://sacj.cs.uct.ac.za/index.php/sacj/rt/suppFiles/408/0
} 


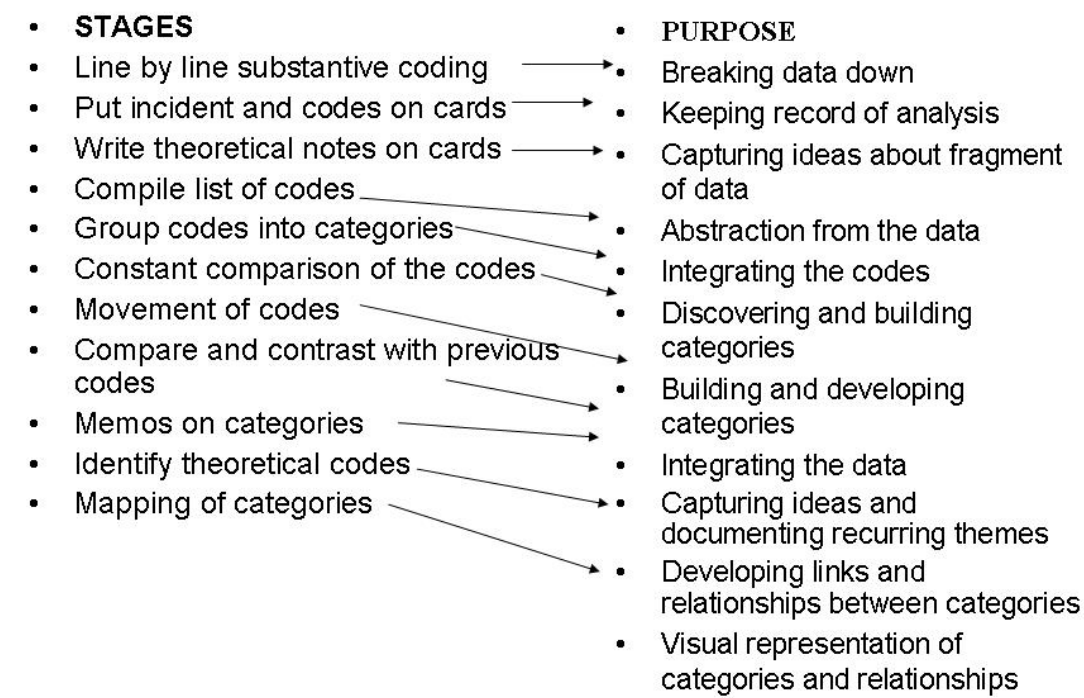

Figure 1: Grounded theory analysis process (Oktay, 2012, p. 17)

Table 1: Top 5 codes and their recurrence in the text

\begin{tabular}{|lr|}
\hline Code & Frequency \\
\hline Code: Who is in charge? & 17 \\
Code: Collaboration is needed across sectors on ICT skills & 14 \\
Code: Different strategies to deal with the challenge & 8 \\
Code: Predict the future ICT skills needed & 7 \\
Code: There is a skills shortage & 7 \\
\hline
\end{tabular}

relationship between concepts (phenomena), conditions and actions/interactions. The resulting relational statements are referred to as theoretical memos. During memo writing, the data that were fractured during coding are now reconstructed and the categories are related to other categories using a combination of deductive and inductive thinking (Barker, Jones, \& Britton, 2017).

In this paper, the theoretical memos formed the basis of the findings. The final stage of Grounded Theory analysis is to systematically integrate, refine and relate the categories around super-categories to result in a substantive theory (Oktay, 2012). This stage of Grounded Theory is presented in the conclusions section.

The next section presents the findings using the three propositions as sub-headings; the meaning of ICT, reflections on curricula and accreditation, contextualising ICT skills to the NDP. 
Table 2: Code categories

\begin{tabular}{|lr|}
\hline Code families & Codes in family \\
\hline The ICT skills challenge is real - and may be a pending crisis & 23 \\
A call for a central coordinating agency & 22 \\
Different strategies to deal with the problem & 17 \\
Academia under pressure & 16 \\
Complexity of ICT: How to manage or predict the future of & 15 \\
a fast-changing and dynamic ICT industry & \\
Change the curricula & 14 \\
Government: How to deal with competing constituents & 13 \\
A call for collaboration & 12 \\
Sarcasm at government and its thick skin & 9 \\
A call for a paradigm shift & 7 \\
A divided academia & 5 \\
Academics: Teething frustrations & 4 \\
An important issue across the board & 4 \\
A divided government & 2 \\
Academia perceives a different mandate & 2 \\
\hline
\end{tabular}

\subsection{The meaning of ICT}

\subsubsection{ICT innovation complicates the real and perceived demand for ICT skills}

The application of ICT is more pervasive today, and its growing embeddedness into many sectors and facets of life means that the boundaries of ICT skills are increasingly blurred. ICT is now found in non-traditional ICT areas such as in the creative industries, crime and many others:

now we are seeing technology embedded into other things that you don't even know it is there. Someone had designed it and implemented it. It is everywhere and more and more now we are hearing the internet of things. The information society is increasing now. Cybercrime is the big deal...

One of the resultant challenges becomes how to measure such transdisciplinary areas and to locate a discipline owner (Schofield, 2014). For example, who is responsible for cybercrime which now affects unsuspecting people in rural areas who now have access to smartphones and are being fleeced of their meagre incomes through the infamous '419' scams? 419 scams are an advance fee scam that was heightened by internet technologies in which fraudsters promise potential victims large sums of money in return for a small upfront fee (Cohen, 2003).

The above finding suggests that in articulating the meaning of ICT, efforts should also be placed in learning from studies in transdisciplinarity. 


\subsubsection{Defining future ICT today}

It was interesting to note the courage of industry in making predictions about the future of ICT. Academics tend to prefer working with data than make bold statements of what the future holds. For example, industry boldly asserted;

we have the four pillars... mobile...big data... social - and cloud... all of these together. . . is going to give rise to a potential fourth platform... it is very much organic... [and it] is incredibly important... to understand what skills are required for the third platform...

the future is on robotics, it's on natural interfaces, it's on 3D printing, the internet of things. The common denominator is the Internet of Things.

Based on such bold assertions it follows that industry demands to have graduates who are ready with these skills (Schofield, 2014). Industry and government expect that their recommendations of the future will be taken up by academia in redesigning their curricula to meet the future and current ICT needs (Scott, 2015). Specifically, industry identified as the number one challenge the ability to find skills that meet new and emerging ICTs.

We need to design for the future, the platform, the technologies that we are working with, and in five years or two years' time are not going to be the same ones we are using now... You need someone that can take those basic principles and go[es] and apply them to each of these new technologies coming through. That is what we [industry] need. We need to design for the future now.

The hard skills are one thing and it's when you get to the soft skills that challenges tend to arise.

think outside of the box and that is one of the key challenges and that starts with education.

The finding indicates the complexity in defining ICT and the related skills. The finding also suggests the need for another educational layer in academic institutions above and beyond traditional ICT curricula to achieve the inherent expectation of a 'better rounded, flexible and progressive' graduate.

\subsubsection{Government on ICT skills}

It was understandably confusing for government as to why there is a skills challenge yet there are unemployed graduates.

Department of Labour have about 3 million unemployed people in their database including graduates ... and when you go to them to say please give this [foreign] person a Department of Labour certificate so that they can get a visa, they [say], 'How come? We have this number of people now you want to bring people from the outside. What about South Africans?' 
To make sense of the shortages in various sectors, the South African government has two types of lists for which it seeks to import skills, the critical list by the Department of Home Affairs and the scarce list by the Department of Labour in conjunction with Sector Education and Training Authorities (SETAs). The critical list refers to skills which are in short supply with respect to the national priority projects, the 18 strategic integrated projects (RSA Government, 2013). The scarce list refers to skills which are in the highest demand in South Africa as a whole and for which skills could be imported where necessary. The scarce skills list refers to "skilled people (who) are not available, or they are available but don't meet employment criteria... (and) may not be willing to work outside urban areas or equity considerations aren't met" (Flanagan, 2014).

The above finding highlights the importance of "communicative action" during inter-government collaboration to a point where different government entities have a shared worldview on what ICT skills mean.

\subsection{Reflections on curricula and accreditation}

\subsubsection{An overstretched and restricted academia}

Academics expressed exasperation at why the ICT skills and graduate readiness for industry employment were considered a university problem.

That is not what we do at universities. We have a three year packed curriculum, where we do impart graduate readiness ... We just don't do that ... We work on terrible scarce resources, overworked and underpaid. We need something back. We are not a recruitment channel. We are educators.

there is the challenge of asking Universities to create a jack of all trades ... Where in other parts of the world [is multi-skilling done]? It doesn't work that way.

As universities we are concerned about creating the output [graduates] and once the output is gone, whoever is on the other side will see how to describe that graduate.

The above quotes allude to an already stretched and underfunded academic sector which normally operates within very tight budgets and timelines (Universities South Africa, 2016). The increasing demand for more rounded graduates from academic institutions, free-tertiary education as seen in the disruptive 2016 \#FeesMustFall campaign, along with the declining subsidy support from government means that many Universities may not have the resources to carry out changes to curricula, even if they wanted to.

\subsubsection{Industry demands for already skilled employees}

Industry expressed concern that the current ICT skills do not match the emerging ICT demands. Industry suggested that $75 \%$ of the 62 most influential industry CIOs and ICT decision-makers identified 'finding resources for new and emerging technologies' to be the highest priority (Hagen, 
2015). Research from the Joburg Centre for Software Engineering (JCSE) that annually produces an ICT skills survey report, similarly noted that $45 \%$ of industry believe the ICT skills shortage has a major effect on their business (Schofield, 2014).

This finding resonates the private sector's preference for graduates who are ready to positively contribute to achieving the bottom line, rather than investing in training graduates at the risk of losing them to the next competitor. Graduates may therefore need an extra 'ready-for-industry' course as part of their ICT skills curricula.

\subsubsection{Raise pre-tertiary education standards}

Another vexation from academia was the quality of students entering University.

the lowered standards in mathematics at basic education level in South Africa results in University students who are unable to grasp the fundamental concepts of specialist ICT concepts or other subjects for which mathematics plays a critical role.

The finding confirms previous claims about the need to have ICT curricula that recognizes the need to improve the mathematics competences of enrolling ICT students (Butgereit, Botha, \& Boysen, 2015; Hunt, Rankin, Schöer, Nthuli, \& Sebastiao, 2009; Spaull \& Kotze, 2015).

\subsubsection{A catch-22 that focuses on teaching new ICT without forward planning}

On average, most students will graduate within three to five years after starting their primary ICT degrees. In industry, the market and demand has already changed within three to five years.

we need to know what skills are needed in 10 years' time so we can design a course now that will be approved in two years to three years' time that will produce graduates four years after that. So it will take seven years for us to design a course, get it approved through internal mechanisms and then get students through the degree. So that is the reality... we are completely stuck... it is an impossible situation.

The findings indicates the challenges of academics registering new curricula in a subject area that is exceptionally dynamic. The finding also suggests having more flexible curricula and and greater agility in the government bureaucracy to approve changes in curricula.

\subsection{Contextualising ICT skills to the NDP}

\subsubsection{Dissonance about the data on ICT skills}

One of the industry leaders challenged the authenticity of the data on ICT skills shortages:

can you believe them [government]? ... One of the things that makes me a little bit uncertain is when the MICT SETA spends several years telling us that there is about 200,000 people employed in the sector and suddenly in one year, it is at 600,000 . Where did that come from? 
Another, an academic delegate, was emphatic that what the government was asking for in terms of imported skills are already being taught and that those graduates struggle to find jobs;

My research is saying that we need people that are mobile developers, SQL developers and that is what is needed by this industry. And from experience ... we have a network course, we teach our students CISCO and when our students are qualified they can't find jobs. $60 \%$ of those guys struggle to find jobs. So what I am saying is that the list [MICT SETA list] is wrong.

How did government come up with that list [of critical and/or scarce ICT skills]? Or who informed that list?

The above finding of dissonance points to the need for more transparency concerning the data that is used to portray the extent of the ICT skills shortage across all the sectors in South Africa. The data could inform efforts in adapting ICT skills curricula.

\subsubsection{Government silos}

ICT in cutting across all ministries and sectors of any nation would be a natural overarching reason for collaboration.

when we talk to the department [another government department] about [skills] ... they don't want to hear anything about this or from us, because we are derailing them from their mission.

One of the long known challenges of any government are the silos within which many departments operate. The finding points to the need to operationalise and go beyond surface discourses and rhetoric to make inter-government collaboration a reality.

\subsubsection{NEMISA (iNeSI) opportunity}

NEMISA's founding mandate was an emancipatory one - one that was premised on taking women from rural areas and introducing them into what was at the time a progressive industry - broadcasting, TV, multimedia and radio (IPSOS, n.d.). The e-skills initiative therefore challenges NEMISA to re-invent itself into more than a developmental training institute to a wider national coordinating public agency on ICT skills.

Only if we had a ministry to deal with that, it [the lack of direction] will stop

The finding suggests that NEMISA has the opportunity to play a central role in coordinating ICT skills efforts between government, industry and academia. 


\subsubsection{Government needs to remain non-partisan}

Every government is driven by a national agenda. In the case of South Africa, the National Development Plan (NDP) 2010 sets the scene that guides decision making in government. The NDP makes it clear that South Africa is a developmental state, with the primary focus on alleviating poverty and reducing social inequality and unemployment. It is therefore understandable that government prefers a solution to importing ICT which solution serves the development agenda in both the short term and long term.

If this expert, that has critical skills can adopt five students and carry those students for four years, are we not going to make a difference in this country?

you find that regionally in the Gauteng province, we have a surplus of certain skills and when you go to other provinces there is nothing.

this is the opportunity to be able as a collective of [ICT] experts to be able to advise further, moving forward on what it is we can do.

have conversations on an ongoing basis... to try and establish what is needed... in 5 to 10 years' time? So that when these students are trained then they are relevantly trained or else we will keep on producing unemployable graduates.

The finding gives an indication at typical government obligations to every citizen regardless of regional location, race or political party. The implication is that government decisions require broad public consultations that could span across ministerial departments and across all other sectors before a decision is implemented - assuming there are few objections. The finding also suggests that contextualising ICT skills may require amendments in government policies that relate to ICT skills.

In the next section, the above findings are summarised.

\subsection{Summary of findings}

The proposition " $P_{1}$ : The inability to succinctly box ICT into one meaning could have something to do with the ICT skills paradox" was supported by the findings. The different sectors are aware and acknowledge their differences in perspective about ICT and the resultant ICT skills. Each sector therefore approaches ICT skills rather differently. The implications for theory and practice are to recommend that rather than attempt to have a succinct definition of ICT or the accompanying ICT skills, a dynamic and transdisciplinary approach using communicative action could be considered. The transdisciplinary exercise would result in a shared national view of ICT and the corresponding ICT skills.

The proposition " $\mathrm{P}_{2}$ : Accreditation of ICT skills curricula may assist in making sense of ICT skills in South Africa" was partially supported by the findings. It stood out that accreditation, which is recognised by all sectors as crucial, is not the challenge. The challenge is in the painstakingly long process of formal accreditation, which long process is antithetical to the current realities of a highly 
dynamic ICT sector. Academics who already feel overstretched and underpaid, are therefore not particularly keen to make changes to curricula unless the change is necessary. The implications are therefore to a rethinking of accreditation policy and in creating an enabling environment that allows academics to work with other sectors in recommending changes to curricula in a quick and flexible way.

The proposition " $P_{3}$ : ICT skills strategies in South Africa should be influenced by the NDP" was not supported by the findings. The findings rather showed a mistrust between the sectors. The mistrust was further reflected within the government sector itself, whose sub-sectors tend to work in silos. The implication of this finding suggests the need for a trusted entity that is able to collaborate between the three sectors and across the different government sub-sectors.

In the next section, the paper draws inferences and recommendations from the findings presented in this section.

\section{CONCLUSIONS}

The paper sought to make sense of the ICT skills paradox in South Africa through discourse using a panel session composed of leaders in academia, government and industry. The discourse was guided by Jürgen Habermas' theory of communicative action. The paper identified three propositions relating to the complexity in ascribing meaning to ICT, accrediting ICT skills curricula, and aligning ICT skills strategy to South Africa's National Development Programme (NDP). The discourse data was analysed using techniques from grounded theory. The findings supported the proposition that ICT cannot be boxed into one succinct meaning. The findings only partially supported the proposition about the importance of accreditation but revealed the process of accreditation as the challenge. The findings did not support the proposition that the ICT skills strategies in South Africa are influenced by the NDP.

\subsection{The need for flexible and agile accreditation processes}

The accreditation may nonetheless need to innovate beyond the traditional accreditation models to ensure quick turnarounds to recommendations for changes to the curricula at both tertiary and government levels. The innovations in the accreditation process would need to make three important considerations;

- Conscientiously evaluate industry suggestions on emerging ICT.

- Recognise the existing resource limitations of most tertiary institutions.

- Make more efficient and quick the accreditation processes at the university and government side. 


\subsection{The need for a trusted national entity with open knowledge}

In terms of alignment with national strategy, the greatest need was for a central coordinating body to steer the collaboration efforts between academia, government and industry. That body would need to make recommendations based on data that is acceptable to all. Such data would need to be transparent and open to all entities to evaluate and independently review. Such open data on ICT skills would feed into curricula recommendations suitable to South Africa. Open and transparent data would further satisfy the requirement for broad public consultations (The World Bank, 2017). The following are therefore the key recommendations on ICT skills strategies.

- Establish or empower a central coordinating body on ICT skills development that connects between industry, academia and government.

- Make data on the national ICT skills status available for scrutiny by all sectors

\subsection{Adopt transdisciplinary approaches}

The findings showed the futility in attempting to ascribe one succinct definition to what ICT means for different sectors. The complexity suggests the need to consider how transdisciplinary fields deal with the proverbial 'wicked' problem (Ackoff, 1981). Problems are regarded as 'wicked' when they have many dimensions to them, are loaded with social and political connotations, and any attempt to solve or structure the problems only creates other new problems. Transdisciplinarity accepts that the social and economic problems of society are increasingly complex and interdependent, not isolated to particular sectors and are often not predictable (Thompson Klein, 2004). Such 'wicked' ICT skills paradoxical problems are not formulated in scientific terms but are rather formulated using everyday terms and language, by 'specialists of everyday life'. The paper therefore makes the following recommendation:

- Adopt transdisciplinary practices in e-skills and ICT skills development strategies.

\subsection{A framework for creating a shared worldview on ICT and ICT skills in South Africa}

The paper, on reflection, identifies a danger in assuming strict dichotomies from Habermas' (1984) categorizations of social interactions as either communicative or strategic action. The paper rather recommends that the two types of social interactions are complementary rather than antagonistic. At a point, strategic action is required when there are movements towards a shared worldview on what ICT skills means to a context. In such a scenario, the 'leaders' in the shared worldview should attempt to influence the reluctant others to accept the strategies on how to effect the shared worldview. Yet, even with such strategic action, there will still need to be a place for communicative action as society nor ICT remain static. The leaders and proponents of strategic action therefore need to continually remain in active communicative debate so that their strategic actions may be appropriately influenced and adapted to arrive at the new shared worldviews. 
The paper therefore submits the following process in Table 3 below as the substantive theory on how to move towards a shared meaning of ICT skills.

Table 3: A Substantive Theory for creating shared meaning about ICT skills

\begin{tabular}{|c|c|}
\hline $\begin{array}{l}\text { Begin with } \\
\text { communicative action }\end{array}$ & $\begin{array}{l}\text { Communicative action uses discourse to create shared meaning. Transdisciplinarity } \\
\text { presents a structure on creating shared meaning between disciplines that have } \\
\text { different notions of reality. The shared meanings become in themselves a reality of } \\
\text { their own with a new set of language (Nicolescu, 2014; Nicolescu and Ertas, 2013). } \\
\text { 1. Appreciate the different levels of reality concerning ICT and ICT skills } \\
\text { - Discuss and identify the conceptual and real boundaries of each sector. } \\
\text { For example, industry is profit-driven while government is national } \\
\text { driven. } \\
\text { 2. Appreciate the included middle concerning ICT and ICT skills } \\
\text { - Discuss and identify the differences and contradictions between each } \\
\text { sector. For example, industry prefers efficiency over consensus while } \\
\text { democratic government prefers consensus over efficiency. } \\
\text { 3. Create universal interdependence with a new shared meaning } \\
\text { - Build new bridges between the sectors where all sectors benefit. For } \\
\text { example, create a new competence area where formal flexible } \\
\text { accreditation is awarded. }\end{array}$ \\
\hline Move to strategic action & $\begin{array}{l}\text { The new shared meanings are translated into action through a central coordinating } \\
\text { agency. } \\
\text { 1. Implement the recommendations. }\end{array}$ \\
\hline $\begin{array}{l}\text { Loop communicative } \\
\text { action regularly }\end{array}$ & $\begin{array}{l}\text { The nature of society suggests that shared meaning is not static but dynamic. } \\
\text { Communicative action therefore needs to be conducted regularly. } \\
\text { 1. Schedule regular communicative action sessions between the different } \\
\text { sectors. }\end{array}$ \\
\hline
\end{tabular}

\subsection{Contributions to research and limitations}

The paper found value in the choice of a qualitative inductive epistemology to conduct the research. The qualitative approach allowed the investigation to uncover more findings than were originally anticipated. Qualitative approaches are appropriate for use in conditions where there is little existing theory or in conditions where the research under investigation is not well structured.

The paper has also made a theoretical contribution in the creation of a substantive framework for creating shared meaning about ICT skills. There is little research in Information Systems that has considered the importance of creating a shared meaning in ICT skills from the different sectors of a society. 
The paper was limited in its data from one panel session. For further research, the above substantive theory (framework) would need to be validated with data and refined through usage.

\section{References}

Ackoff, R. (1981). The art and science of mess management. Interfaces, 11(1), 20-26. https://doi. org/10.1287/inte.11.1.20

Barker, T., Jones, S., \& Britton, C. (2017). An introduction to grounded theory. Last accessed 19 Nov 2017. Retrieved from http://methods.sagepub.com/video/an-introduction-to-groundedtheory

Butgereit, L., Botha, A., \& Boysen, V. (2015). Confessions of a Dr. Math tutor. In H. Crompton \& J. Traxler (Eds.), Mobile learning and mathematics: Foundations, design and case studies (pp. 187-197). Routledge.

Calitz, A. P., Greyling, J. H., \& Cullen, M. D. M. (2014). South African Industry ICT graduate skills requirements. In B. Clayton \& K. Naude (Eds.), Southern African Computer Lecturers' Association (SACLA) (pp. 25-26).

Calitz, A. (2017). Personal correspondence with chairman, SACab.

Career Junction. (2017). Executive summary. Vaccine, 30, xi. https://doi.org/10.1016/S0264410X(12)01439-9

Charmaz, K. \& Mitchell, R. G. (2001). Grounded theory in ethnography. In P. Atkinson, A. Coffey, S. Delamont, J. Lofland, \& L. Lofland (Eds.), Handbook of ethnography (pp. 160-175). https: //doi.org/10.4135/9781848608337

Cohen, F. (2003). Internet fraud: Mythical online scams. Computer Fraud and Security, 2003(4), 19. https://doi.org/10.1016/S1361-3723(03)04013-2

Coulson, C. (2014). ICT skills shortage: A clear and present danger. Last accessed 08 Dec 20108 Dec 20177. Retrieved from https://istart.com.au/feature-article/ict-skills-shortage-a-clearand-present-danger/

Coyne, I. (2009). Grounded theory. Trinity College School of Nursing and Midwifery.

Dreyfus, S. E. \& Dreyfus, H. L. (1980). A five-stage model of the mental activities involved in directed skill acquisition. Last accessed 19 Nov 2017. https://doi.org/10.21236/ADA084551

Everhart, R. B. (1986). Review: Ethnography in Educational Evaluation by David M. Fetterman; Ethnography and Qualitative Design in Educational Research by Judith Preissle Goetz, Margaret Diane le Compte. Contemporary Sociology, 15(3), 450-451. https://doi.org/10.2307/ 2070078

Flanagan, L. (2014). State's Top 100 most wanted skills. Last accessed 19 Nov 2017. Retrieved from https://www.iol.co.za/news/south-africa/gauteng/states-top-100-most-wantedskills-1695677

Gefen, D., Ragowsky, A., Miller, J., Licker, P., \& Stern, M. (2015). The center cannot hold: How leading firms are managing the changing IT boundaries. Communications of the Association for Information Systems, 36(33), 655-667. 
Glaser, B. (1978). Theoretical sensitivity: Advances in the methodology of grounded theory. Sociology Press.

Glaser, B. (1992). Basics of grounded theory analysis: Emerging vs. forcing. Sociology Press.

Glaser, B. \& Strauss, A. (1999). The discovery of grounded theory: Strategies for qualitativer research. Aldine.

Habermas, J. (1972). Knowledge and human interests. Heinemann Educational.

Habermas, J. (1979). Communication and the evolution of society. Heinemann.

Hagen, L. (2015). Where IT meets business - The South African skills imperatives. In Proceedings of the IDC South Africa CIO Summit Series 2015, Johannesburg, South Africa.

Hunt, K., Rankin, N. A., Schöer, V., Nthuli, M., \& Sebastiao, C. (2009). Blind Admission? The ability of NSC maths to signal competence in university commerce courses as compared to the former SC Higher Grade maths. Last accessed. Retrieved from https://mpra.ub.unimuenchen.de/18075/

Ikamva National eSkills Institute. (n.d.). What is iNeSI? Last accessed 19 Nov 2017. Retrieved from http://www.inesi.org.za/about-inesi/what_is_inesi.php

IPSOS. (n.d.). About us. Last accessed 19 Nov 2017. Retrieved from https://www.ipsos.com/en/ about-us

Kelle, U. (2007). "Emergence" vs. "forcing" of empirical data? A crucial problem of "grounded theory" reconsidered. Historical Social Research-Historische Sozialforschung, 6(2), 133-156.

Lazonick, W. (2006). Globalisation of the ICT labor force. In R. Mansell, C. Avgerou, D. Quah, \& R. Silverstone (Eds.), The oxford handbook on ICTs. Oxford University Press.

Lofland, J. \& Lofland, L. (1984). Analyzing social settings (2nd). Wadsworth.

Lyytinen, K. \& Klein, H. K. (1985). The critical theory of Jurgen Habermas as a basis for a theory of information systems. In E. Mumford (Ed.), Research methods in information systems (pp. 219236). Elseview Science Publishers.

Oktay, J. (2012). Grounded theory. Oxford University Press. https://doi.org/10.1093/acprof: oso/9780199753697.001.0001

Oluwajodu, F., Blaauw, D., Greyling, L., \& Kleynhans, E. P. J. (2015). Graduate unemployment in South Africa: Perspectives from the banking sector. SA Journal of Human Resource Management, 13(1), 1-9. https://doi.org/10.4102/sajhrm.v13i1.656

Orlikowski, W. \& Iacono, C. S. (2001). Research commentary: Desperately seeking the 'IT' in IT research-A call to theorizing the IT artifact. Information Systems Research, 12(2), 121-134. https://doi.org/10.1287/isre.12.2.121.9700

RSA Government. (2010). National development plan 2030: our future - make it work. Last accessed 08 Dec 2017. Retrieved from https://www.gov.za/issues/national-development-plan-2030

RSA Government. (2013). National infrastructure plan. Last accessed 08 Dec 2017. Retrieved from http://www.gov.za/issues/national-infrastructure-plan

Runciman, B. (2015). Manifestos making the UK the IT place to be. ITNOW, 57(1), 48-51. Last accessed 19 Nov 2017. https://doi.org/10.1093/itnow/bwv022

Sahay, S., Mukherjee, A., Yaqub, S., \& Westrup, C. (2015). Capacity strengtheninig in a development context: Institutional challenges and approaches. In P. Nielsen (Ed.), IFIP9.4: Proceedings of 
the 13th International Conference on Social Implications of Computers in Developing Countries (pp. 149-157).

Schofield, A. (2014). 2014 JCSE ICT skills survey. Last accessed. Retrieved from https://www.jcse. org.za/sites/default/files/\%5bfilename\%5d_2.pdf

Scott, R. (2015). Higher education in America. Remaking college. Princeton University Press.

Sein, M. \& Harindranath, G. (2004). Conceptualizing the ICT artifact: Toward understanding the role of ICT in national development. Information Society, 20(1), 15-24. https://doi.org/10. 1080/01972240490269942

Southern African Computer Lecturers' Association. (2014). Minutes of the Head of Department (HOD) colloquium held on Wednesday, 25 June at $13 \mathrm{~h} 00$ at NMMU, Port Elizabeth. Last accessed 19 Nov 2017. Retrieved from http://www.sacla.org.za/SACLA2014/SACLA\%202014\% 20HoD\%20Colloquium\%20minutes\%20(Approved).pdf

Spaull, N. \& Kotze, J. (2015). Starting behind and staying behind in South Africa. International Journal of Educational Development, 41, 13-24. https://doi.org/10.1016/j.ijedudev.2015.01.002

Strauss, A. (1987). Qualitative analysis for social scientists. Cambridge University Press.

Strauss, A. \& Corbin, J. (1990). Basics of qualitative research: Grounded theory procedures and techniques. Sage. https://doi.org/10.1017/CB09780511557842

The Information Economy Council. (2014). The Information Economy Council digital skills strategy. Last accessed 19 Nov 2017. Retrieved from https://www.thetechpartnership.com/globalassets/ pdfs/research-2014/informationeconomydigitalskillsstrategy_oct14.pdf

The World Bank. (2017). Benefits of open data. Last accessed 19 Nov 2017. Retrieved from http: //opendatatoolkit.worldbank.org/en/starting.html

Thompson Klein, J. (2004). Prospects for transdisciplinarity. Future, 36(4), 515-526. https://doi. org/10.1016/j.futures.2003.10.007

Tomlinson, M. \& Tomlinson, M. (2008). 'The degree is not enough': Students' perceptions of the role of higher education credentials for graduate work and employability education credentials for graduate work and employability. British Journal of Sociology of Education, 29, 49-61. https://doi.org/10.1080/01425690701737457

Twinomurinzi, H. (2012). The role of ICT in sustainable and responsible development: E-Skilling. In H. M.D., W. D., M. W., \& P. J. (Eds.), HCC 2012: ICT critical infrastructures and society. IFIP advances in Information and Communication Technology, vol 386 (pp. 90-99). https: //doi.org/10.1007/978-3-642-33332-3_9

Twinomurinzi, H. (2015). Social cognitive factors affecting career choice in mobile app development: Comparing between employed and unemployed programming students. In Proceedings of the Information Systems Education Conference (pp. 396-407). Retrieved from http://proceedings. isecon.org/download/fb1 qt9nadsapukxjf3fr

Universities South Africa. (2016). Universities funding in South Africa: A fact sheet. Last accessed 19 Nov 2017. Retrieved from http://www. uct.ac.za/usr/news/downloads/2016/ UniversitiesFundingSouthAfrica_FactSheet.pdf 
Zuppo, C. (2012). Defining ICT in a boundaryless world: The development of a working hierarchy. International Journal of Managing Information Technology (IJMIT), 4(3), 13-22. https://doi. org/10.5121/ijmit.2012.4302 


\section{A APPENDIX A}

\begin{tabular}{|c|c|}
\hline Code & Occurrence \\
\hline Code: Who is in charge? & 17 \\
\hline Code: Collaboration is needed across sectors on ICT skills & 14 \\
\hline Code: Different strategies to deal with the challenge & 8 \\
\hline Code: Predicting the future ICT skills needed & 7 \\
\hline Code: There is a Skills Shortage & 7 \\
\hline Code: Government: Aware of the criticisms constantly labeled against it & 6 \\
\hline Code: NEMISA: Emphasis is on collaboration across all sectors & 6 \\
\hline Code: NEMISA: In charge but in transition & 6 \\
\hline Code: NEMISA: Playing a catalytic role & 6 \\
\hline Code: close to all our hearts & 5 \\
\hline Code: Divided we fall & 5 \\
\hline Code: E-skilling & 5 \\
\hline Code: E-skilling: It has different levels & 5 \\
\hline Code: Government: Driven by a national agenda - the NDP & 5 \\
\hline Code: Sarcasm at government efforts & 5 \\
\hline Code: Academic: Feel like caught between a rock and hard place & 4 \\
\hline Code: Certification is not enough & 4 \\
\hline Code: Getting worse & 4 \\
\hline Code: New ICT Skills on demand & 4 \\
\hline Code: Practical skills are needed & 4 \\
\hline Code: Research on ICT Skills in South Africa & 4 \\
\hline Code: Academic: Even universities are divided & 3 \\
\hline Code: Academics & 3 \\
\hline Code: Acknowledge the need for Direction in terms of ICT Skills in South Africa & 3 \\
\hline Code: Central coordination & 3 \\
\hline Code: Crisis exists & 3 \\
\hline Code: Different languages on what skills are anyway & 3 \\
\hline Code: Different sectors & 3 \\
\hline Code: Foreign skills: Majority of the scarce skills are foreign and have to be imported & 3 \\
\hline Code: Government: A confusing problem & 3 \\
\hline Code: Government: Ministerial Silos & 3 \\
\hline Code: Government: Service oriented towards an entire population & 3 \\
\hline Code: How do we measure the skills shortage? & 3 \\
\hline Code: ICT Innovation complicates matters & 3 \\
\hline Code: Industry & 3 \\
\hline Code: Managing growing user expectations & 3 \\
\hline Code: NEMISA: Assesses missing ICT skills and bridges the gap & 3 \\
\hline
\end{tabular}




\begin{tabular}{|c|c|}
\hline Code & Occurrence \\
\hline Code: NEMISA: Depends on Universities to skill local populations & 3 \\
\hline Code: Paradigm shift is needed & 3 \\
\hline Code: Providing access to a mobile & 3 \\
\hline Code: Sector Body in charge of ICT Skills & 3 \\
\hline Code: Skilling our students to meet industry demands & 3 \\
\hline Code: Academic: Are practical skills our problem? & 2 \\
\hline Code: Bridge the divide between sectors & 2 \\
\hline Code: Change from conservative organisations & 2 \\
\hline Code: Change the way and what we teach & 2 \\
\hline Code: Changing curriculum is not so easy & 2 \\
\hline Code: Cybersecurity & 2 \\
\hline Code: Demand & 2 \\
\hline Code: Demand: Experience and industry opportunities & 2 \\
\hline Code: Dissonance between government list and industry skills needed & 2 \\
\hline Code: Frustration & 2 \\
\hline Code: Government: Collaboration across departments is ongoing and creates passionate debates & 2 \\
\hline Code: Government: Gate keepers to imported needs & 2 \\
\hline Code: Government: It has a deliberate definition linked to national strategic objectives & 2 \\
\hline Code: ICT jobs are trending & 2 \\
\hline Code: ICT soft skills & 2 \\
\hline Code: Industry attempts to link up to Universities & 2 \\
\hline Code: Is there a real problem? Let's look at the research & 2 \\
\hline Code: NEMISA: Skills in partnership with Universities & 2 \\
\hline Code: Not business ready & 2 \\
\hline Code: Questionable data on ICT Skills & 2 \\
\hline Code: Regional imbalances & 2 \\
\hline Code: Specialist ICT skills are needed & 2 \\
\hline Code: Academic: A paradigm shift away from old image a challenge & 1 \\
\hline Code: Academic: an over focus on graduating people & 1 \\
\hline Code: Academic: Approving new qualifications takes at least 2 years & 1 \\
\hline Code: Academic: Expect government to do research on predicting emerging technology trends & 1 \\
\hline Code: Academic: Internal processes are also constraining to fast development & 1 \\
\hline Code: Academic: Other countries are doing that kind of research & 1 \\
\hline Code: Academic: Predicting the future and creating courses that take 2 years to approve is a challenge & 1 \\
\hline Code: Academics: In their own world - head in the clouds and the feet as well & 1 \\
\hline Code: Advisory Boards to ICT faculties & 1 \\
\hline Code: Archaic technology & 1 \\
\hline Code: Archaic training institutions & 1 \\
\hline Code: Assign the body in charge with more resources & 1 \\
\hline Code: Changing and more location-averse workforce & 1 \\
\hline Code: Decision time? & 1 \\
\hline Code: End users are more IT savvy - and expect more & 1 \\
\hline
\end{tabular}




\begin{tabular}{|lc|}
\hline Code & Occurrence \\
\hline Code: Global ICT organisation & 1 \\
Code: Government and some industry does not really know how to define the ICT sector & 1 \\
Code: Government: Gets confused from different messages from industry and academia on ICT skills & 1 \\
Code: Government: Good intentions do not always materialise & 1 \\
Code: Government: Home Affairs & 1 \\
Code: Government: How to ensure that qualifications are authentic & 1 \\
Code: Government: Open to ideas & 1 \\
Code: Government: Recognise the challenge of unemployed graduates & 1 \\
Code: Government: Why is there a problem & 1 \\
Code: Graduates are unemployable because they are not good enough & 1 \\
Code: ICT is dynamic and cross-cutting & 1 \\
Code: ICT skilled people have a sub-culture of their own & 1 \\
Code: ICT skills challenge is a global problem & 1 \\
Code: ICT4D & 1 \\
Code: Influential IT leaders in industry & 1 \\
Code: IT is integral to everything & 1 \\
Code: jack of all trade approach & 1 \\
Code: Little is known what Government does & 1 \\
Code: NEMISA: Also monitor global competitiveness & 1 \\
Code: NEMISA: Still has a focus on disadvantaged communities & 1 \\
Code: Problems attributed to fundamental education & 1 \\
Code: Quasi-government on ICT Skills & 1 \\
Code: Service nature of ICT department & 1 \\
Code: Skills retention strategies & 1 \\
Code: Technical skills are not appreciated by students & 1 \\
Code: There are efforts but not well known out there & 1 \\
Code: Time lag in teaching ICT & 1 \\
Code: Undue influence of aggressive vendors? & 1 \\
Code: Unemployed ICT graduates & 1 \\
\hline
\end{tabular}

